\title{
PROPORTIONAL RATIOS AND GEOMETRICAL SETUPS FOR ACHIEVING THE HOVERING EFFECT OF ARCHITECTONIC STRUCTURES
}

\author{
Vladan Nikolić, Ljiljana Radović, Olivera Nikolić, Biserka Marković, Petar Mitković, Mihailo Mitković, \\ Jelena Đurić
}

In the entire period of development of human civilization, there has been a continuity of the concept of "hovering" architectonic structures. This paper deals with discovering the idea of "hover" structures in numerous historical examples and in various architectural styles. The reasons of such formal shaping are utilitarian, but also conceptual and esthetic. Through an analysis of the continuity of the idea and formal appearance of the mentioned structures, the methods of achieving the effect can be defined and classification resulting from them made. In this paper, the achievement of the floating effect of architectonic structures has been analyzed from the aspect of ratios and geometrical setups in design process.

Keywords: architectural design; geometrical setups; "hovering" architecture; proportional ratios

Proporcijski odnosi i geometrijske postavke za postizanje efekta lebdenja arhitektonskih objekata

Prethodno priopćenje Kontinuitet ideje "lebdećih" arhitektonskih objekata, postojao je kroz čitavo razdoblje razvoja civilizacije. U ovom radu istražuje se ideja "lebdećih" prostornih struktura kroz povijesne primjere u različitim arhitektonskim stilovima. Razlozi takvog formalnog oblikovanja su od utilitarnih, do apstraktnih i estetskih. Kroz analizu kontinuiteta ideje i oblikovne pojavnosti spomenutih objekata dolazi se i do načina postizanja efekta i klasifikacije koja iz njih proizlazi. U ovom radu je postizanje efekta lebdenja arhitektonskih objekata analizirano s aspekta proporcijskih odnosa i geometrijskih postavki u procesu projektiranja.

Ključne riječi: arhitektonsko projektiranje; geometrijske postavke; "lebdeća" arhitektura; proporcijski odnosi

\section{Introduction - Human primordial desire to fly (hover)}

"Eventually, architecture is nothing else than a form given to ideas." [1]
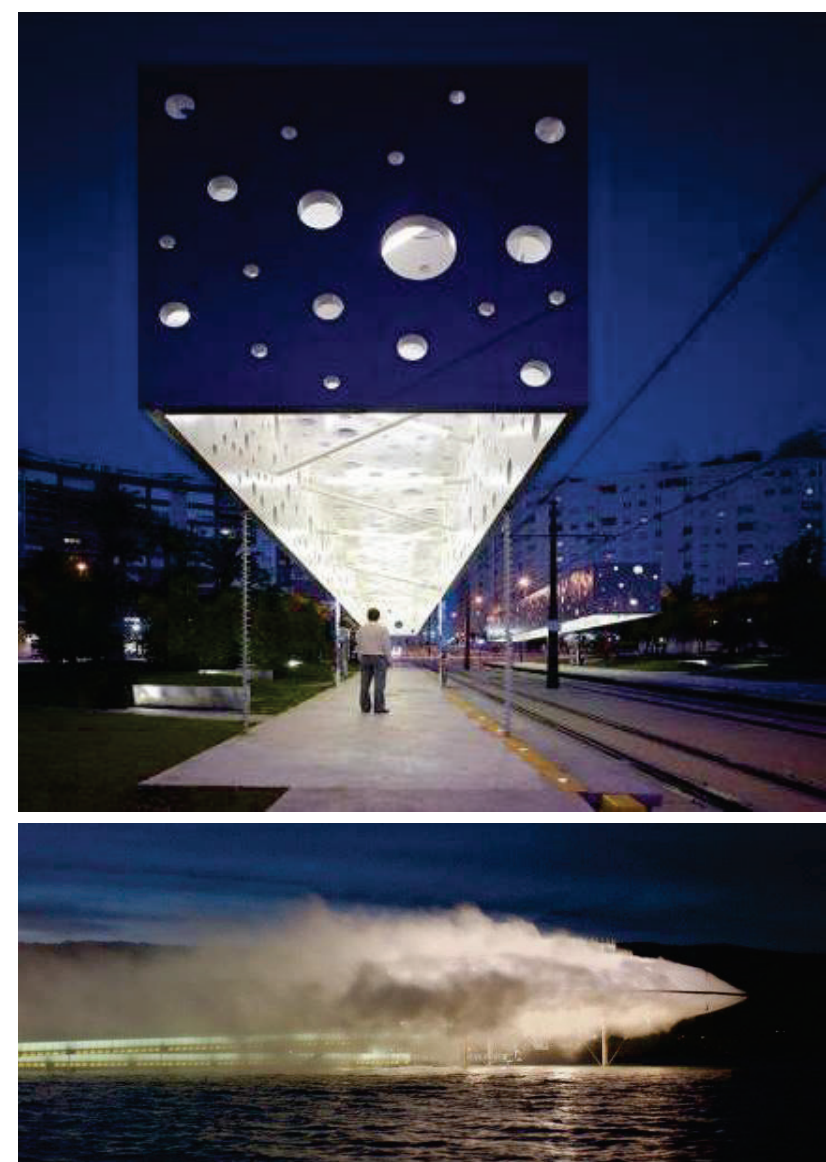

Figure 1 Tram Stop in Alicante, Spain, 2006 (Subarquitectura) and Blur Building, Switzerland, 2002 (Diller + Scofidio)
Since the times when humans acquired selfawareness and environment awareness, they became fascinated by the phenomena they could not stand up to. The wish to grow bigger than the limitations and the very nature itself, was powering the civilization from the very beginning. This arrogance of the self-aware creatures, who said "Needs must when the devil drives", inevitably conquered many limitations of the nature and of the human mind. The latter is even more significant, because it was inherent to man and his limitedness. This conquest of the self was evident in all aspects of the society, and the victory in architecture occurred in $20^{\text {th }}$ century, in the heroic age of modernism. The moment man realized he was free of certain inhibitions, the progress went on with incredible impetus [2]. The dream of flying was, for centuries, being "realized" only in myths and fairy-tales, such as the myth of Icarus and Daedalus, ideas of angels, flying carpets, Castles in the air in fairy tales and novels, $[3 \div 7]$ etc., Fig. 2 and exactly the myths, legends and fairy-tales represent the archetypal emergence of the idea, and should be observed as a fluid, "inexistent basis" of what happened later. Blur building and Tram Stop in Alicante are contemporary structures built on previous idea, Fig. 1 [8].

Creation of the hovering illusion of architectonic structures obsessed the builders from the dawn of human civilization. Sometimes, the reasons of such approach in building were utilitarian, and sometimes dedicated to achieving the previously mentioned ideal. Irrespective of the reasons of such formal shaping, the mentioned idea has its historical continuity and uninterrupted transition through the styles in architecture. The hovering effect of the architectonic structures is achieved in a complex way, through application of various principles. One of the most important principles is the geometrical preferences and 
proportional relations in architecture of such structures. Focusing on this aspect of the idea, the paper analyzes the principle through analyzing the representative contemporary examples of "hovering" architectonic structures.
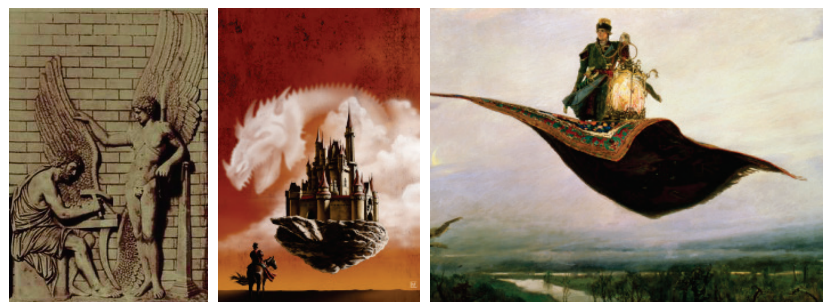

Figure 2 Icarus and Daedalus, Castle in the air and Flying carpet

\section{Historical continuity and transition of the idea through styles}

"Since the completion of the Pyramids, the architecture becomes ever lighter, and in the $20^{\text {th }}$ century, this process will accelerate, and it will become even lighter." [9]

This paper deals with formal-aesthetic aspects of "hovering" architecture, which are directly related to the geometrical aspects. In this research were abstracted a large number of "hovering" architectural structures, so as to cover as broad temporal and geographic context. That unequivocally proves the existence, continuity and universality researched ideas and principles. There is a continuity of the observed idea regardless of the architectonic styles, applied materials, historical circumstances and other influential factors. Since the structures have become lighter, in an objective, material sense, in addition to intensive ongoing formal research, one may talk of geometrical progression of development in the future [10].

Pile dwellings are the structures built on piles above the ground or water, Fig. 3. It is one of the oldest methods of construction, and the first in the historical tracking of the continuity. The oldest pile dwellings date back to Neolith and Bronze Age. The remains of the pile dwellings can be found in the Alps, South America, and can still be actually seen in Southeast Asia, West Africa. Also, the remains of Neolithic pile dwellings were discovered in Scotland and Scandinavia. This group of structures originally came to being for practical reasons of safety and sufficient in the sense of security of their dwellers, meaning this was a utilitarian inception of the idea, which later underwent all sorts of transformations [2]. In this context of utilitarity, that is affordances and achieved effect far beyond the original meaning [11].

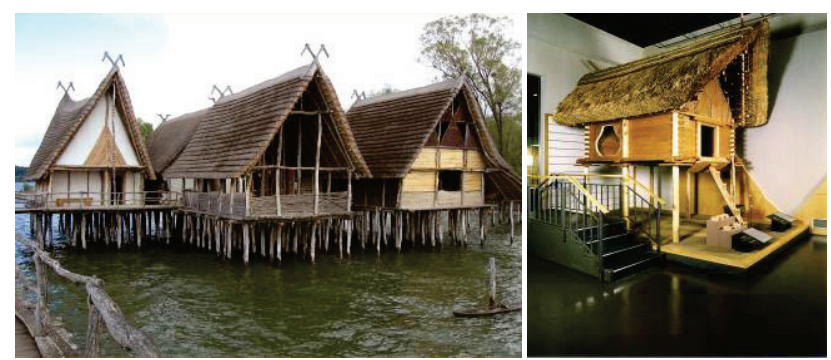

Figure 3 Pile dwellings in an open air museum in Zurich and an elevated stilt house in Japan
Oil rigs are contemporary industrial pile dwellings supported over the surface of the sea. There are numerous examples showing massive rigs and few slender supports making them appear to be hovering or floating over the sea, particularly in harsh weather and choppy seas. Contemporary pile dwellings are the exploration posts and stations on the Antarctica, raised on pillars for purely practical reasons, Fig. 4.
Figure 4 Oil rigs in the North Sea and B

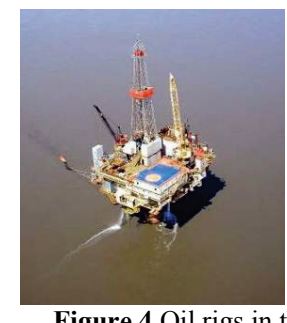

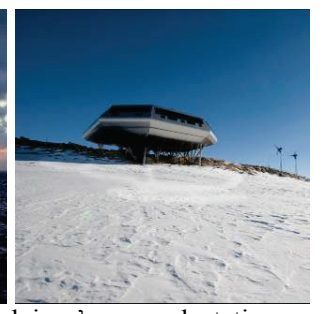

on Antarctica
The historical examples of the structures achieving the hovering illusion can be rarely encountered in an architecture where the prevailing building material was stone or brick, which is the case in the history of the European civilization since ancient times until the $19^{\text {th }}$ century. The examples in which continuity of the idea can be considered are Venice, the city on water, and the medieval bridge Vecchio in Florence, which carries craftsmen workshops buildings along its entire span. The massive bulk of superstructure of the bridge, in respect to the columns, as well as the relations of colors, materials, light-and-dark almost creates an effect of hovering over the river. Attempts to relieve the structures from weight, applying more modern constructions, can be observed only in the opus of Viollet-le-Duc, Fig. 5 [12].
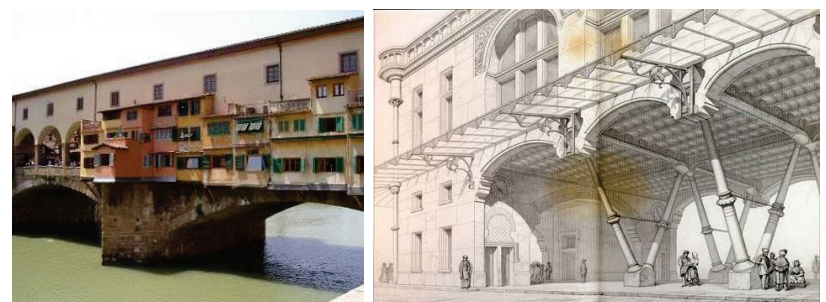

Figure 5 Ponte Vecchio, Florence and innovative constructions of Viollet-le-Duc
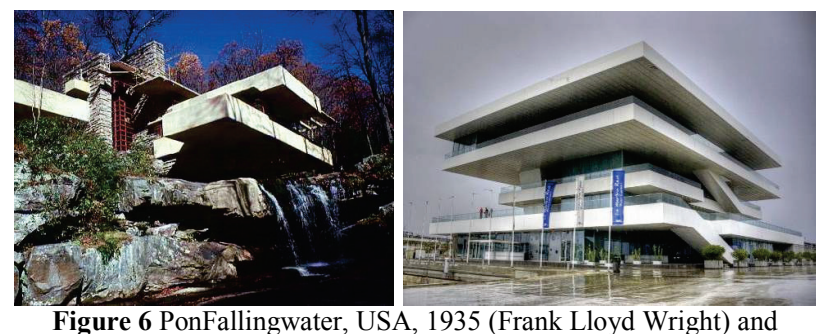

igure 6 PonFallingwater, USA, 1935 (Frank Lloyd Wright) and America's Cup Building, Spain, 2006 (David Chipperfield)

The later examples of $20^{\text {th }}$ century, such as the House over the Waterfall by Frank Lloyd Wright represent the idea of continuity in the western civilization, facilitated primarily by the implementation of reinforced concrete and modern steel structures. The Waterfall house encroaches the waterfall, and massive horizontals of concrete slabs appear as a free structure of hovering elements in space oblivious to gravity, Fig. 6 [13]. A 
similar method of achieving the effect can be seen in the contemporary building, at the turn of the $21^{\text {st }}$ century, America's Cup Building in Valencia, which is one of the evidences of transition of the idea through the historical styles, Fig. 6.

There are numerous examples of structures which create a hovering illusion, regardless of the original idea of their designers, in the opus of the modernist architects of the $20^{\text {th }}$ century, Le Corbusiers, Mies van den Rohe, Kenzo Tange, but also of many others. Le Corbusier's vision of architecture was greatly affected by the journey in the Balkans and near East. The near East houses habitually have roof terrace, most often on slender columns. The most famous example is the Semiramis' Hanging Gardens, one of the seven wonders of the ancient world. The displayed structures achieve the hovering illusion by being elevated above the terrain, on elegant columns, by the play of light and shadow, and by whiteness of erected bulks. The continuity of the considered idea might to the greatest extent be found in most of the Le Corbusier's buildings, Fig. 7 [14].

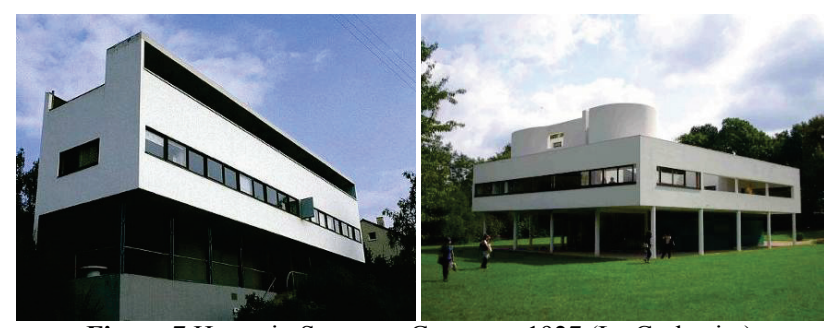

Figure 7 House in Stuttgart, Germany, 1927 (Le Corbusier) and Villa Savoye, Poissy, France, 1929 (Le Corbusier)

Numerous designs of Mies Van de Rohe create a hovering illusion. In the case of the displayed house, it was done primarily for utilitarian reasons, but the hovering effect is extremely successful either when there is ground below the structures or the water during high water season. A particular dynamics is provided by the access plateau elevated above the ground, Fig. 8 [2].

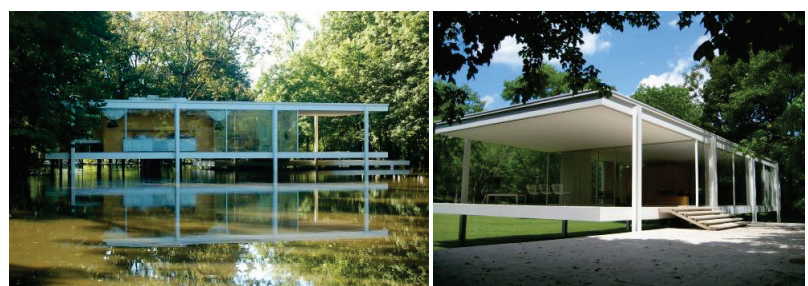

Figure 8 Farnsworth House, USA, 1951 (Miss Van der Rohe)

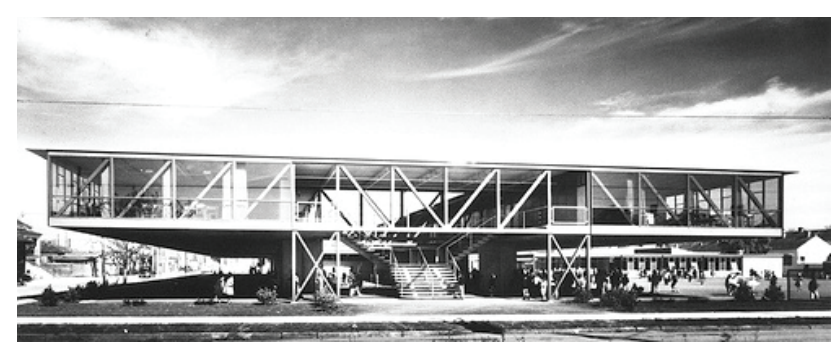

Figure 9 Phillis Wheatley Elementary School, USA, 1954 (Charles Colbert)

In 1954, the architect Charles Colbert constructed an elevated cantilevered steel truss structure to provide an expansive shaded playground area, protecting the schoolchildren from the tropical climate. Being progressive for a school facility at the time, the building was acclaimed and its design was exhibited internationally. The building is a valuable example of regional modernism and the idea of hovering architecture, Fig. 9 [15].

In Fig. 10 the examples of the structures from east Europe and former USSR are presented [16, 17], where the hovering effect of the entire structures or their parts was achieved. These are examples of socialist architecture of the $20^{\text {th }}$ century in this region.
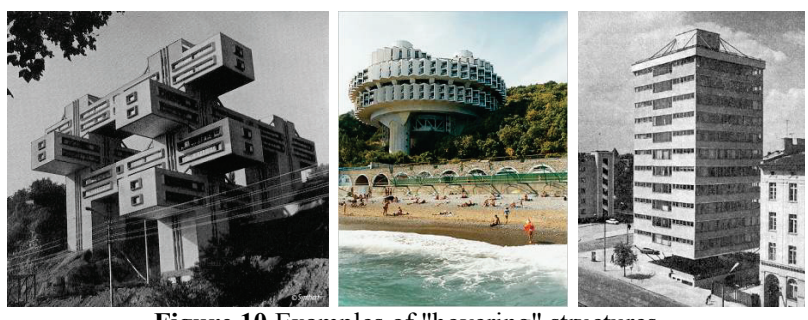

Figure 10 Examples of "hovering" structures from Tbilisi, Yalta and Warsaw

Oskar Niemeyer's designs are particularly interesting for this review, particularly those where he often used the effect of hovering structures. Contemporary materials and technology of construction enabled the most obvious realization of this idea in the examples shown in Fig. 11 $[2,18]$.

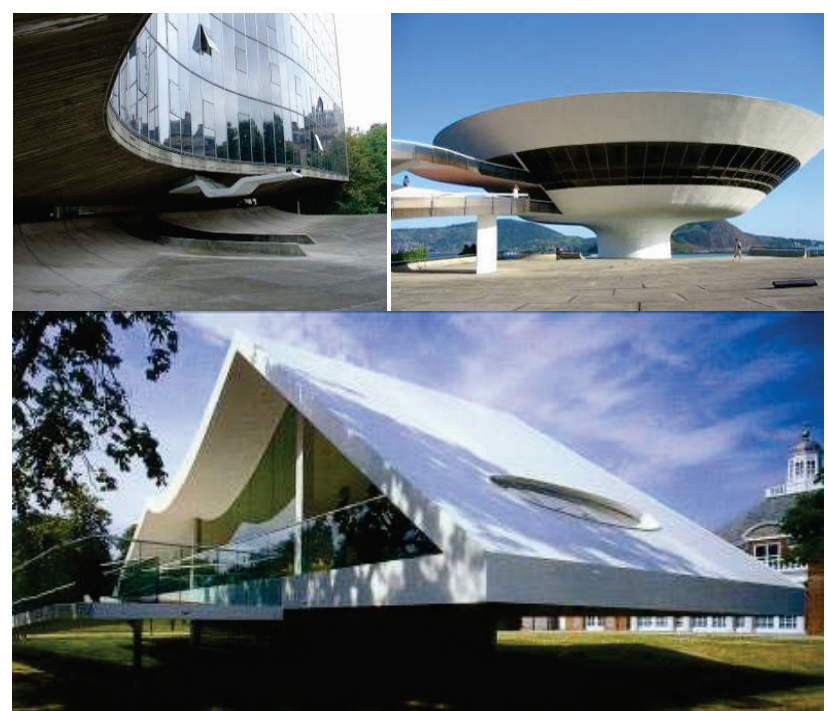

Figure 11 Communist Party Headquarters, France, 1972, Niterói Contemporary Art Museum, Brazil, 1996 and Serpentine Gallery Pavilion, GB, 2003 (Oscar Niemeyer)

The vernacular architecture and the architecture without architects have been and still are supporting the continuity of the concept we are discussing. Often, those are contemporary examples of houses in the trees, mountain cabins in inaccessible locations, but also humorous designs such as the Kubicek's Flying Cathedral from the Czech Republic, Fig. 12. In fact, it is a balloon in the shape of a cathedral. The idea is as old as a dream of flying, and it was realized in an imaginative way. Sometimes incidental circumstances bring about the discussed effect, such as in the case of the devastated building in Fig. 12 [2]. 

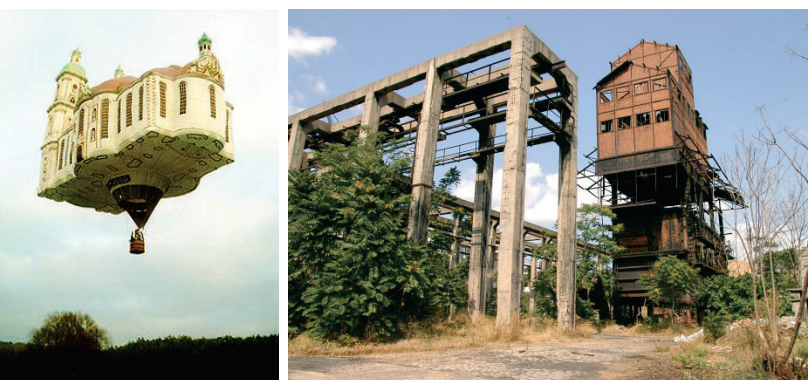

Figure 12 Kubicek, Flying Cathedral, Czech Republic and example of randomly generated effect

Contemporary architecture is supported by powerful computer software and new engineering materials and technologies. This has relieved the architects from the previous centuries' limitations and constrictions and enabled them to freely express themselves, focusing themselves on the essence of the idea and the more convincing achievement of the hovering effect.

Regarding that the future undoubtedly brings a qualitative and quantities expansion of the idea studied in the architecture, it is necessary to anticipate some guidelines of its development. Exactly there lies the contribution of the Utopists whose visions remained only on paper, but intrigued anyone who encountered them. It is probable that exactly those visions and designs were the engine of the development of architecture, by being so bold and intentionally premature. The works of the Russian constructivists in the 20 's of the $20^{\text {th }}$ century contained this idea of hovering architectonic structures, and became an inspiration of many generations of architects [19]. In Fig. 13 the "Horizontal skyscraper" by Lissicky and its contemporary interpretation is presented. Also, the Malevich's "Cities into the air" of the Lavinski's project "the city on springs", etc. should be mentioned [2].
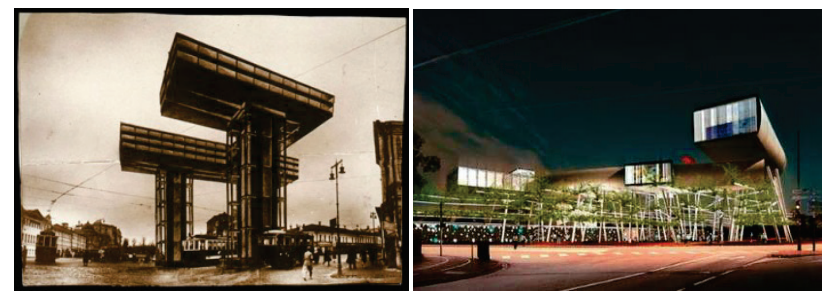

Figure 13 El Lissicky, "Horizontal skyscrapers",1925

and a contemporary interpretation of a similar idea

Lazar Khidekel's architectural visions transcended the rhetorical games of the revolution by developing complete cities out of sublime architecture, Fig. 14. Long before Friedman's Architecture Mobile, Constant's New Babylon, and Isozaki's Clusters in the Air, Khidekel imagined a world of horizontal skyscrapers that through their Suprematist weightless dynamism seemed to float ad infinitum across the surface of the earth [20].

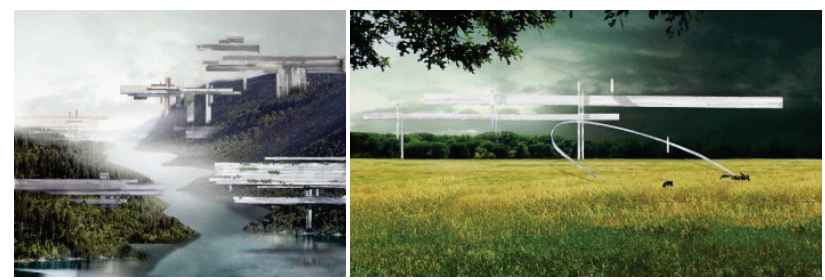

Figure 14 Futuristic City and Aero City, $1928 \div 1932$

(Lazar Khidekel) (Photomontage by WAI Think Tank)
Buckminster Fuller and Shoji Sadao presented the design for Floating Cloud Structures (Cloud Nine), around 1960. Cloud Nines are self-contained communities of several thousand people living inside a mile wide enclosed geodesic spheres, which float over the earth's surface. The same authors produced Dome Over Manhattan (1960), marvelous representations of a Buckminster-dreamed future, Fig. 15 [21].

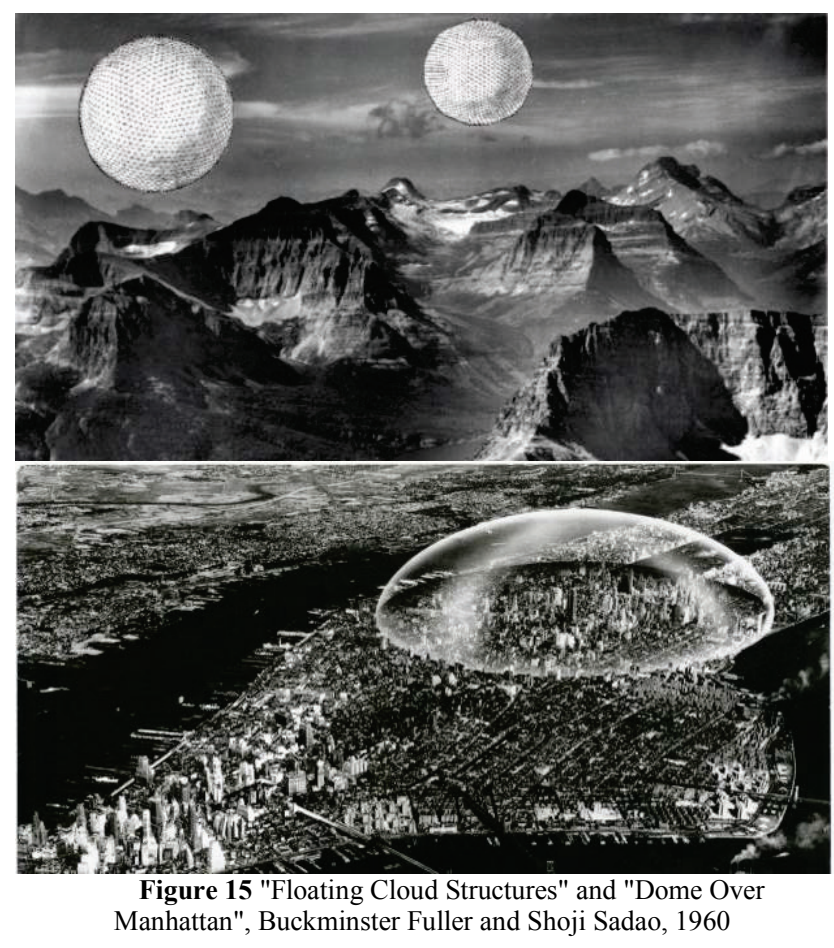

In the early 1960 's a design for a floating city for Tokyo Bay was commissioned. After the death of the projects original Japanese patron in 1966, the project was taken over by the United States Office of Housing and Urban Development. Pictured is a single neighborhood module of this "Triton City" designed to house 6500 people. Arata Isozaki in 1962 proposes the town planning design of the city of the future "Clusters in the air", Fig. 16. Later, in 2012, White said: "Floating cities could redefine human existence" [22].

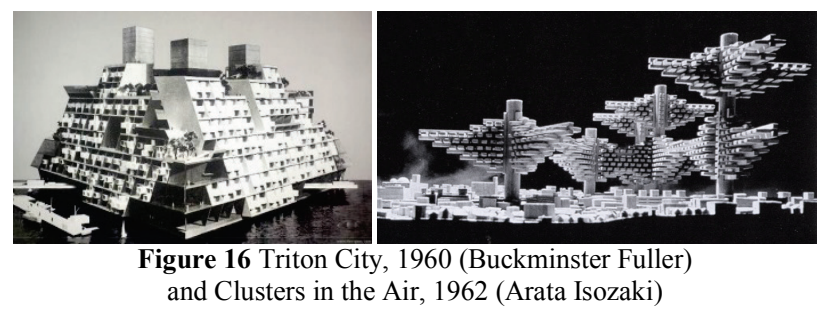

The works of Archigram group were being influenced by Antonio Sant' Elia's works as well as by Buckminster Fuller and Yona Friedman. Their projects considered some elements of the idea of hovering architectonic structures, like Ron Herron's "The Walking City" in 1964 and pneumatic "Seaside bubbles" in 1966, Fig. 17 [23].

The competition proposal for Symbolic World Cup Structure uses an abstract hovering cloud, which can be lowered and raised above the space of the square, and 
constitutes an adaptable and highly visible element in the city, Fig. 18 [24].

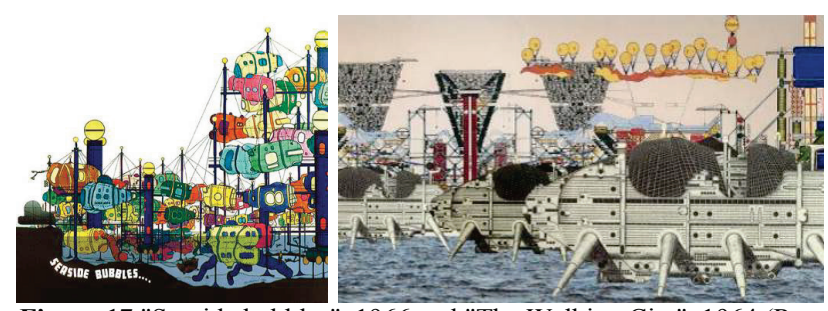

Figure 17 "Seaside bubbles", 1966 and "The Walking City", 1964 (Ron Herron, Archigram)

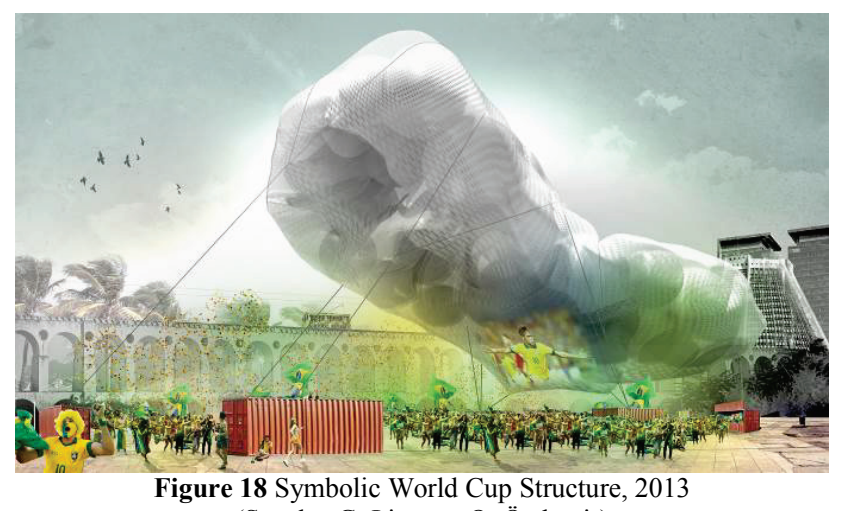
(Specks, G. Lizama, O. Özdemir)

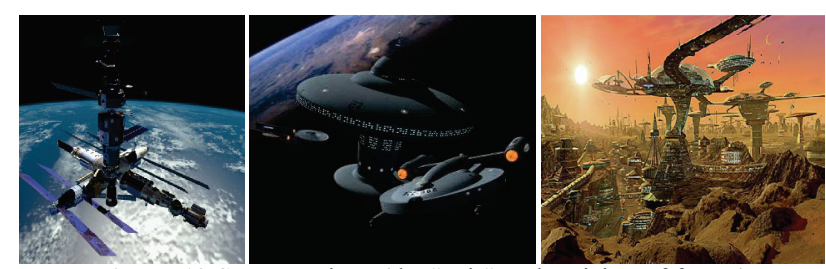

Figure 19 Space stations (the "Mir" and a vision of future) and vision of Mars City

In this review of the idea continuity, one should certainly cast a glance at the projections of the future, and they are inevitably related to the outer space. When discussing the space and weightlessness, the space stations are structures which are objectively hovering in space. The first space stations, US "Skylab" and Russian "Mir", were the first structures of this kind. These structures are far from the futuristic visions, but the trail has been blazed. Future generations of architects will deal with formal and functional shaping of structures in space, Fig. 19.

\section{Geometrical setup, proportional ratios and classification of structures in terms of how the hovering effect has been achieved}

Architecture is the image we see [25]. Spiro Kostof says: "Buildings are often born of images and live on images" [26], so the illusion created in the eye of the beholder can be considered a reality of the observed structure. Fig. 20 shows Calatrava's sculptures where hovering effect can be found.

It can be said that there are only two components of accomplishing the effect of hovering structures, Fig. 21:

- $\quad$ subjective (only visual accomplishment of the effect by creating illusion in the eye of the beholder)
- objective (visual accomplishment of the effect when a structure has no supports indeed - when it hovers).

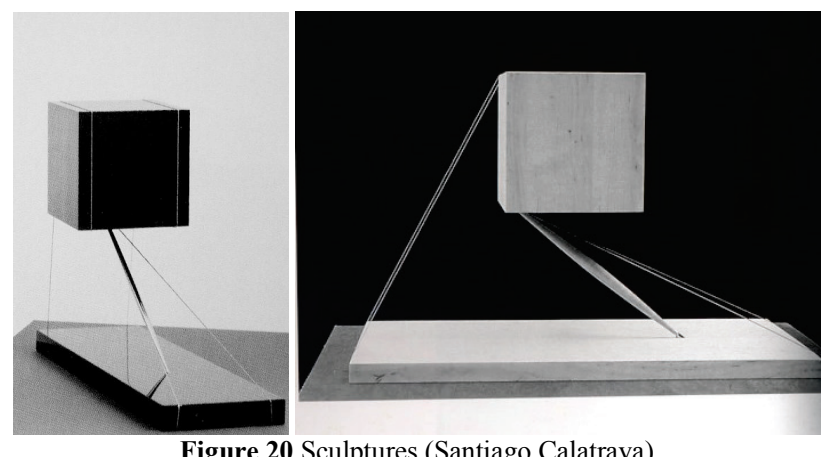

Figure 20 Sculptures (Santiago Calatrava)

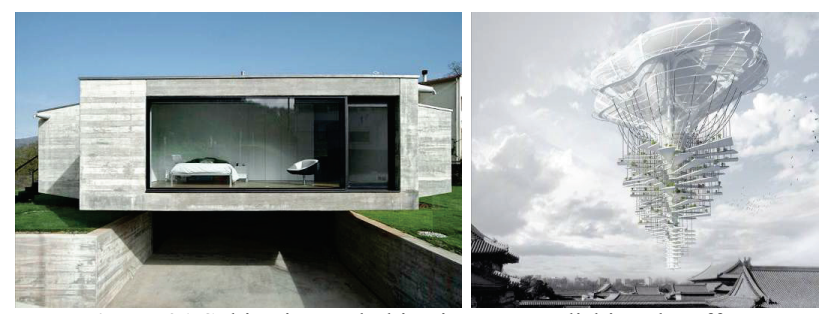

Figure 21 Subjective and objective accomplishing the effect of hovering structures

The fundamental geometrical setup of the hovering structure is its separation from the surface, in the space where it is situated, Fig. 22. In case when a part of the structure is separated, the part of the structure on the soil can be considered the surface.
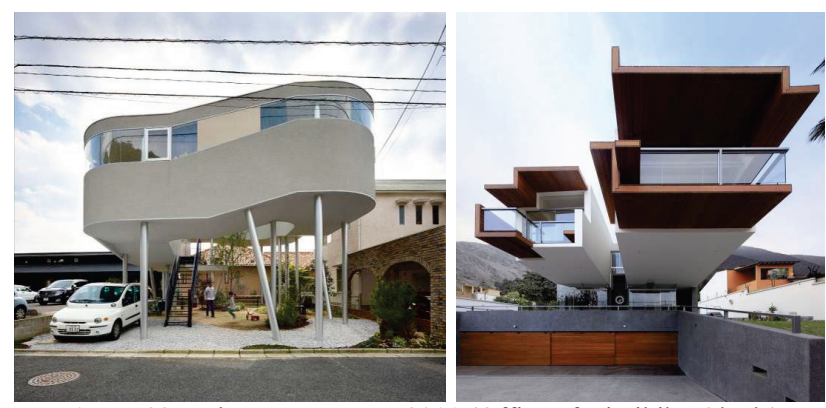

Figure 22 Toda House, Japan, 2011 (Office of Kimihiko Okada) and A House Forever, Peru, 2013 (Longhi Architects)

Regarding the gravitational pull, the floating effect (illusion) is primarily achieved by using of visual concealment, or "visual relieving" of the supports. It is achieved by implementing the structural systems allowing large and wide cantilever elements above the slender supports, and by hanging the structures on the thin cables, of negligible thickness, Fig. 23.

The successfulness of the geometrical setup depends on the designer's skills, such as proportional relationships applied in formal shaping. By combining the previously mentioned parameters, an observer is lead to wonder how a structure can stand and exist in the field of gravity. Therefore, the hovering effect of architectonic structures in the gravity field is more or less a successful optical illusion [27]. With this in mind, apart from the objective component necessary for achieving the effect, the subjective component is also important. The perception of an observer is based on visual experience, i.e. can talk about architecture as memory storage [28]. "Architecture 
has more to do with making frames than painting pictures; it's more a matter of providing an accompaniment to life than the dance itself" [29]. The hovering effect can be objectively achieved, but only in case of architecture on paper, structures under water surface, or structures in weightlessness.
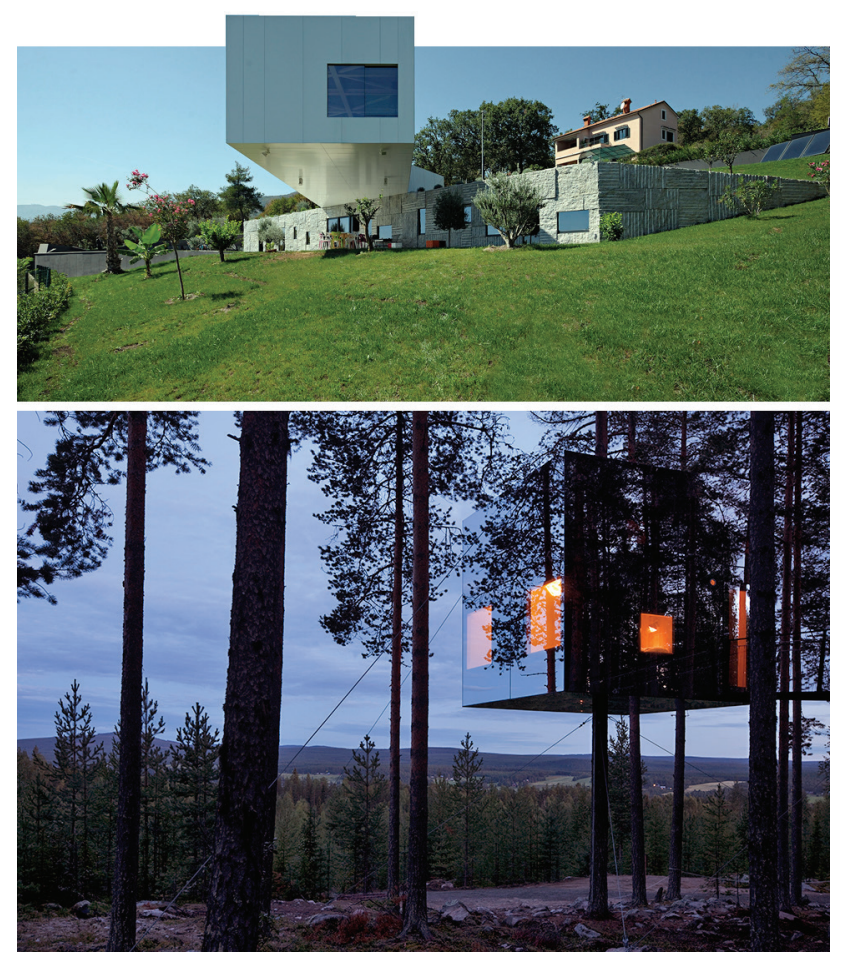

Figure 23 Nest \& Cave house, Croatia, 2012 (Idis Turato) and Treehouse hotel, Sweden
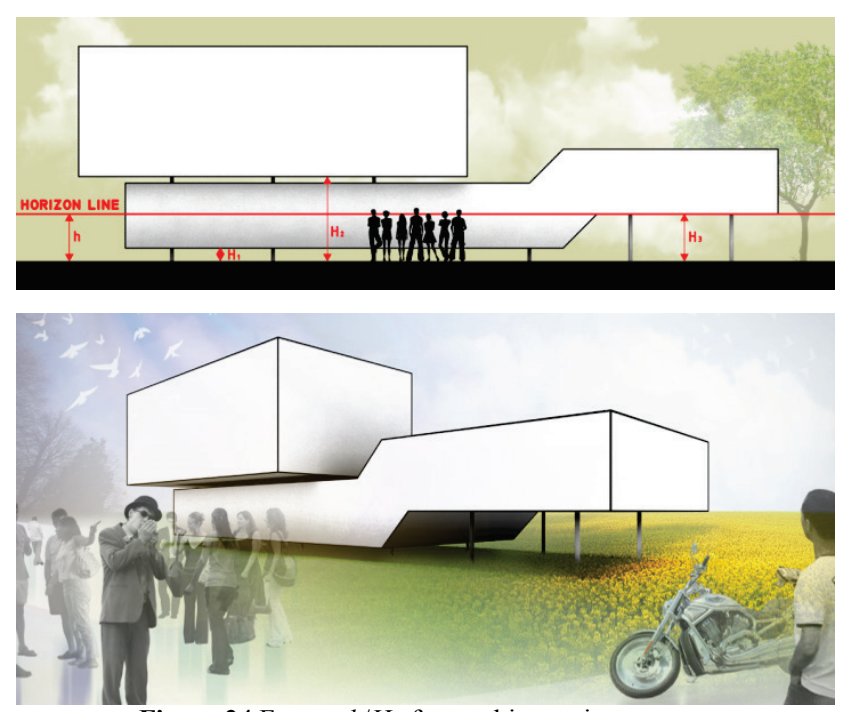

Figure 24 Factors $h / H$ of an architectonic structure

From the geometrical point of view, the position of the elements of a structure in respect to the height of the observer's horizon can be considered [30], as well as their mutual ratio. The $h / H$ factor is the basic parameter of the geometrical setup. It represents the ratio of the elevation of the observer's horizon $(h)$ and the elevation for which the entire structure, or some of its parts, is elevated above the surface $(H)$, Fig. 24:

- In case of $h / H>1$ the structure, or some of its parts, are below the observer's horizon. If this elevation is small, the hovering effect is simply achieved by applying the cantilevers concealing the supports. Particularly successful are the cases when the surface is in contrast with the materialization and color of the structure.

- In case of $h / H=1$ the lower surface of the structure is at the horizon level, which is difficult to achieve in practice due to the terrain configuration and current elevation of the observer's horizon.

- In case of $h / H<1$ the entire structure or some of its parts are above the observer's horizon level. This case is much closer to the concept of hovering structures, but is more difficult to achieve in subjective terms.
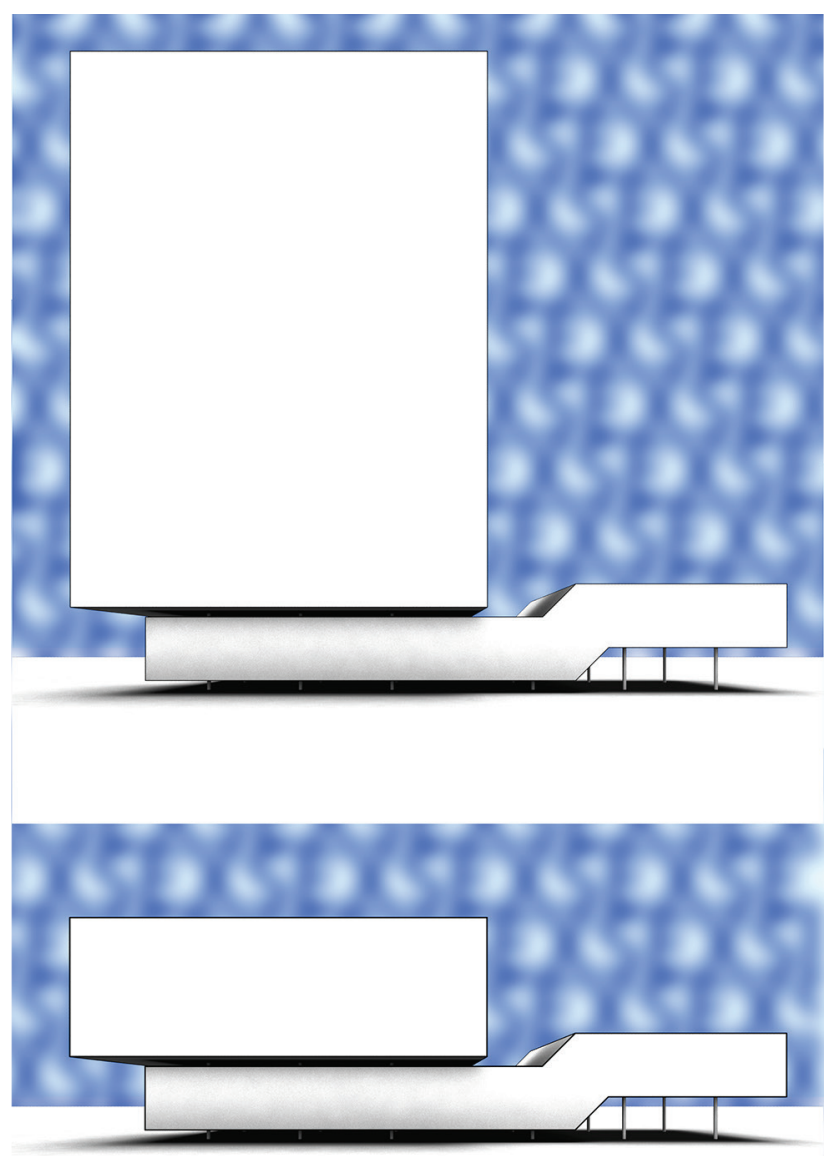

Figure 25 Various ratios of structural elements

The ratio primarily comprises the ratio of the height of the structure, or part of the structure, to which the hovering effect is implemented, and the height of its separation from the surface. The higher the ratio, the effect is more convincing regarding the previous experience of the observer of the mass of the structure, based on its volume. Also, the other ratios in the form of the structure itself and its elements can be a significant generator of this effect, where the designer's skill is fully challenged. This is a matter of a unified and consistent design, aimed at achieving of the desired effect, Fig. 25. 


\subsection{Impact of the ground surface on the achievement of the architectonic structures hovering effect}

The choice of the adequate ground surface can be an essential generator of the effect, and it should maximize visual separation of the structure from the surface. The contrasting surface in terms of material and coloration [31], in comparison to the materialization of the structure itself, a fluid surface or favorable terrain configuration [22], can contribute to the more convincing achievement of the hovering effect of architectonic structures. In Fig. 26 the terrain configuration is one of the key factors. The natural environment and rich vegetation are the elements visually concealing the supports and creating a full contrast to the materials and strict geometry of forms [32].

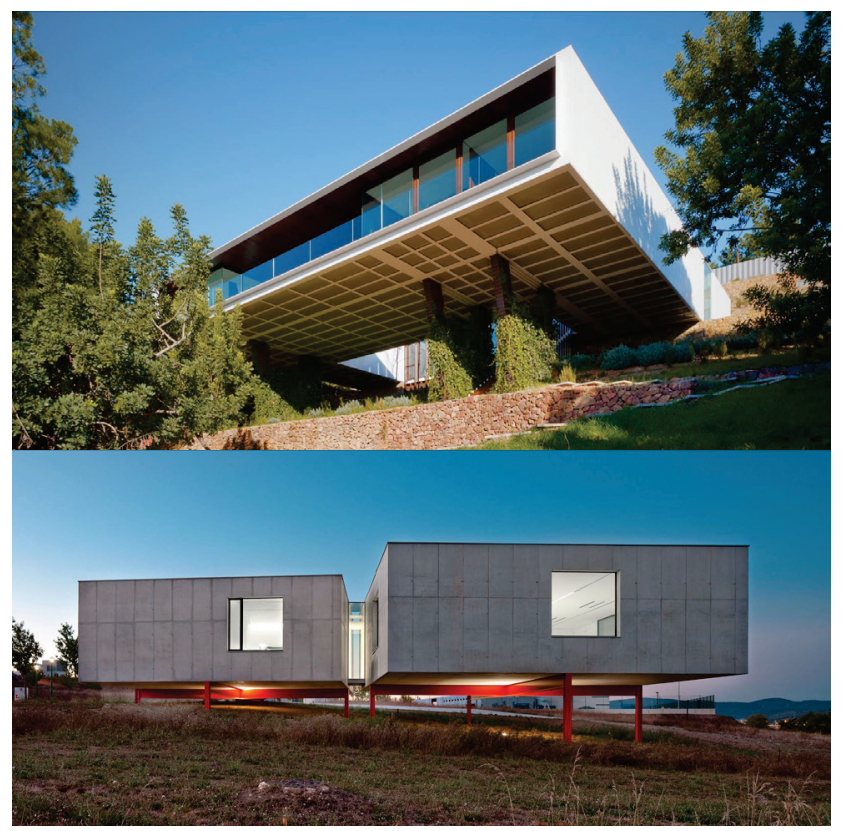

Figure 26 BF House, Spain, 2011 (OAB + ADI) and Biokilab Laboratories, 2010 (Taller Básico De Arquitectura)

Fluid surface, such as water, represents the return to the archetypal context of stilt house, and also the utilitarian context of oil rig. Also specific are the examples of exploration stations on the Antarctica, with the constant snow cover, which is at the same time sufficiently fluid and completely white, which emphasizes this effect, Fig.4.

Visually, it can be used for a base for a new building as an extension of the existing one, different in style, according to the time distance subjectively emphasizes the achieved hovering effect, examples in Fig. 26. DeBrug/deKade hovers above the historical factory complex of Unilever Nederland, and the idea itself is close to the Horizontal skyscraper by El Lissicky. The similar case is the example of the Sharp Centre for Design in Canada, Fig. 27.

\section{2 "Contact surface"}

If the hovering effect is applied for a part of the structure, then there is a "contact surface" between this part and the rest of the structure. In Fig. 28 the possible ratios of the parts of the structure and their "contact surface" are presented, as well as the examples of such ratio in other architectonic structures.
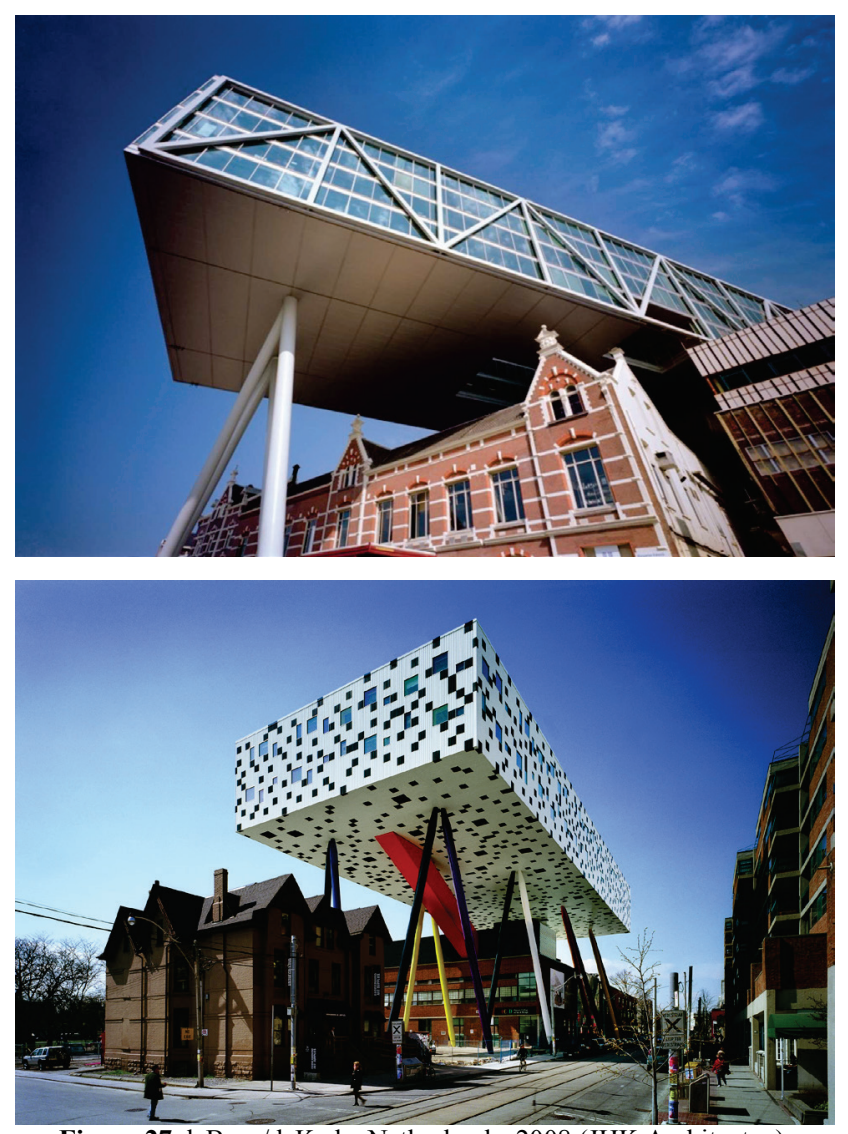

Figure $27 \mathrm{deBrug} / \mathrm{deK}$ ade, Netherlands, 2008 (JHK Architecten)

and Sharp Centre for Design, Canada, 2004 (Alsop Architects)

\subsection{Classification of the methods of achieving the hovering effect of architectonic structures}

The classification of the method of achieving the hovering effect of architectonic structures is made according to the type of surface, that is, environment, as well as according to the $h / H$ factor, Tabs. $1 \div 4$. Regarding that the $h / H$ factor is variable, depending on the height and position of the observer, the ideal limit case $h / H=1$ was not considered.

Classification in case A deals with underwater architectonic structures, or structures built above the water, Tab. 1. Structures with $H=0$ can exists in this case, as a result of fluid ground surface which is a powerful generator of the floating/hovering effect.

Classification in case B deals with structures built above the land, Tab. 2. There can exist architectonic structures with factor $h / H>1$, or $h / H<1$.

Classification in case $\mathrm{C}$ deals with structures built in space, where all structures float weightlessly with no $h / H$ factor, Tab. 3.

Classification in case D deals with architecture which exists only on paper or which has visionary qualities, Tab. 4. 

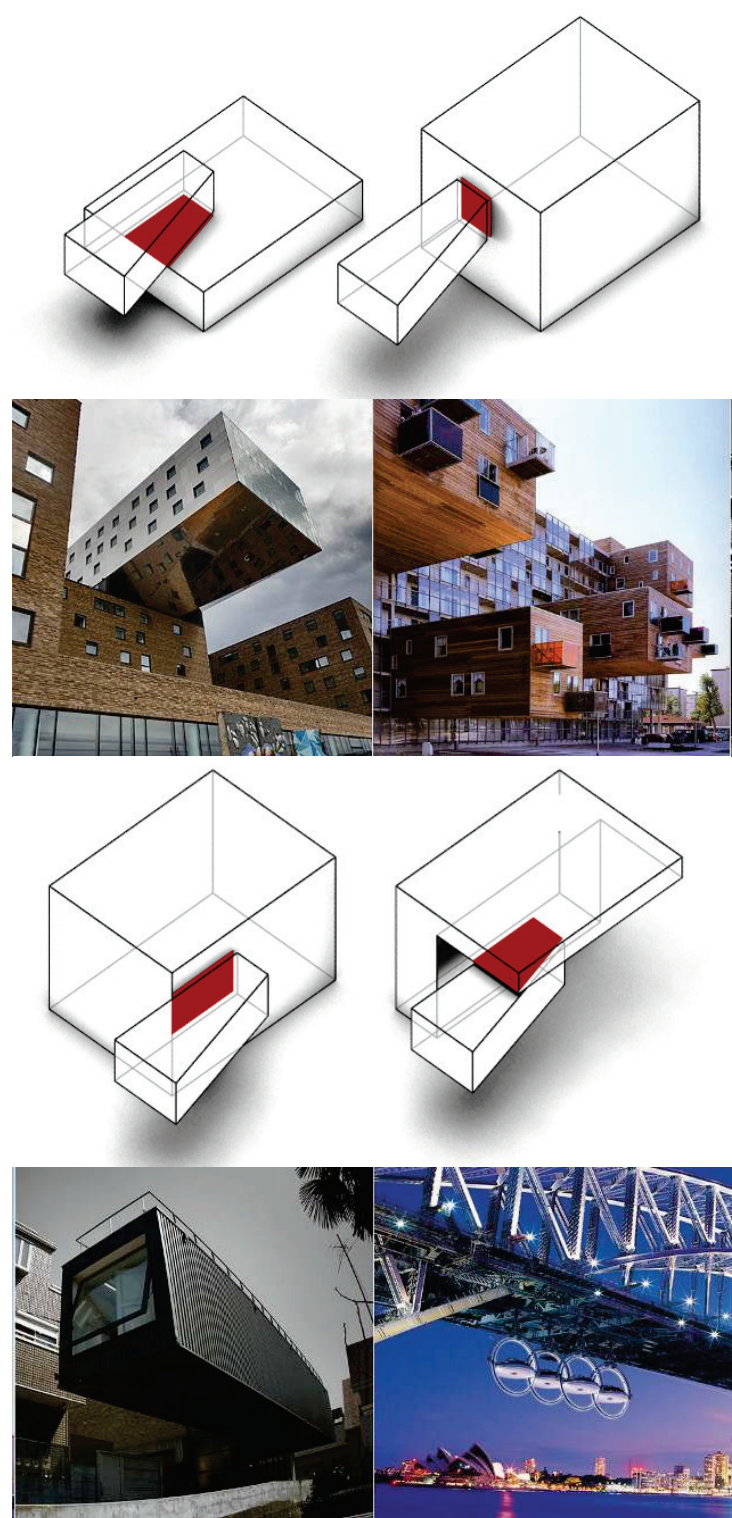

Figure 28 "Contact surfaces" and examples: Hanging building at River Spree, Germany; Wozoco, Netherlands, 1997 (MVRDV); Undercover Lab, Japan, 2001 (Klein Dytham), "The Audi Spectacle" concept, 2010

In the first part of the paper, the continuity of the concept of "hovering" architectonic structures and its transition through historical styles is presented and confirmed. The reasons for such a building approach range from utilitarian to conceptual and esthetic. A particularly large number of such structures was created in $20^{\text {th }}$ and $21^{\text {st }}$ century, regarding the accelerated development of new technologies and construction materials. With the advent of comprehensive application of computers in contemporary construction engineering, architects have been liberated from almost all formal limiting factors. The forms of structures become more complex, and the complicated ones are statically defined and practically constructed. The frequency of application of the hovering effect or architectonic structures rises exponentially, which is a trend to be continued in the future. For this reason the structures in the outer space and architecture "on paper", where the computers facilitate visualization of a large number of avant-garde and bold new concepts have been envisaged [2].
Table 1 Classification of the methods of achieving the hovering effect of architectonic structures (Structures/Water)

\begin{tabular}{|ll|}
\hline A & Structures / Water \\
\hline A1 & Underwater structures \\
\hline & Example: Aquarius Reef Base, USA, 1986
\end{tabular}
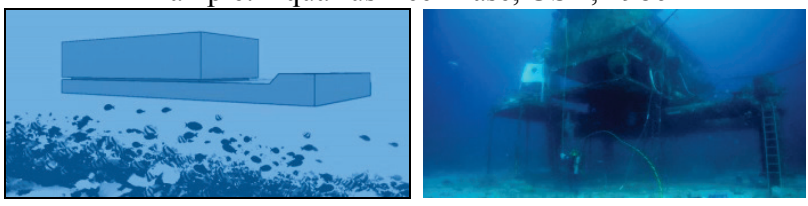

A2 Structures on water

$H=0$, in visual terms, structures are on the very surface of water. Example: Monolith, EXPO 2002, Switzerland, 2002 (Jean Nouvel)

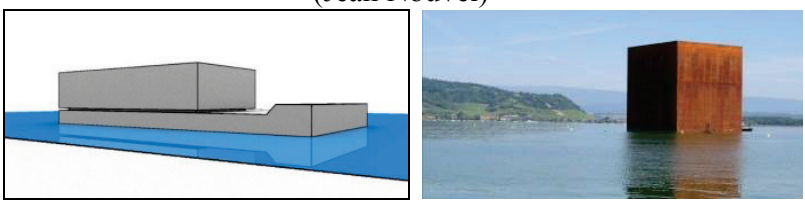

A3 Structures slightly above water

$h / H>1$, the height of the structure above water is lower than the view point of the observer. Example: Raft $4 \mathrm{U}$ - Cafe Restaurant, Serbia, 2012 (Studio Alfirevic)

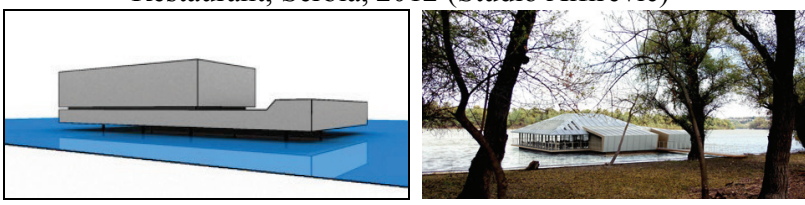

A4 Structures high above water

$h / H<1$, the height of the structure above water is higher than the view point of the observer. Example: Kraanspoor, Netherlands, 2007 (OTH Architecten)
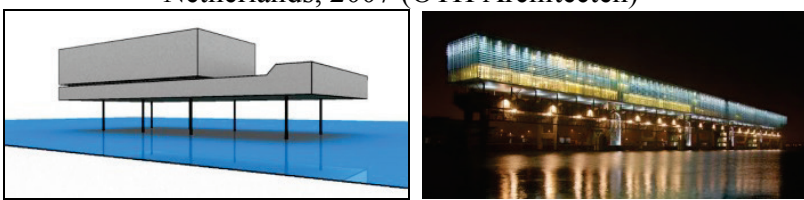

Table 2 Classification of the methods of achieving the hovering effect of architectonic structures (Structures/Land)

B Structures / Land /

B1 Structures slightly above land

$h / H>1$, the height of the structure above ground is lower than the view point of the observer. Example: Tourist Info Center, Serbia, 2006 (Vladan Nikolić, Olivera Nikolić)
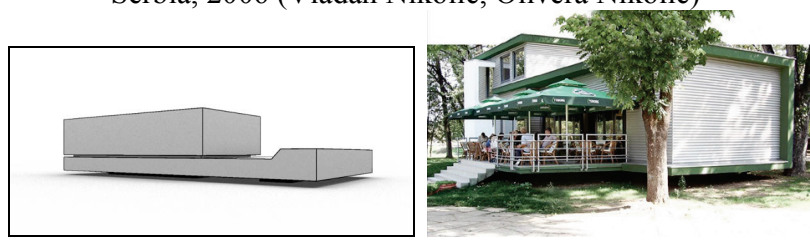

B2 Structures high above ground

$h / H<1$, the height of the structure above ground is higher than the view point of the observer. Example: Rudin House, France, 1997 (Herzog \& de Meuron)

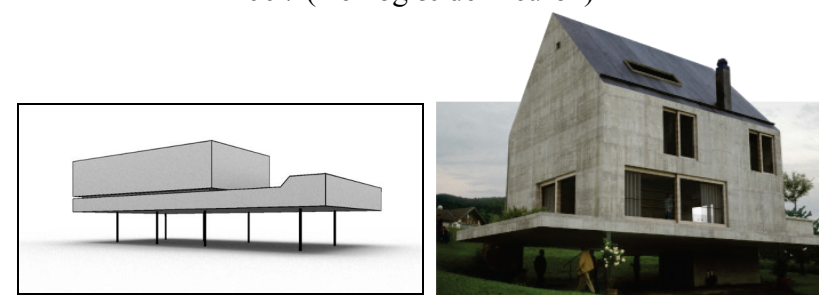


Table 3 Classification of the methods of achieving the hovering effect of architectonic structures (Structures/Space)

C Structures/Space

Example: International Space Station, 1998
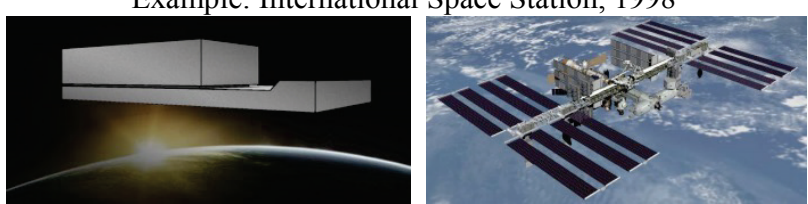

Table 4 Classification of the methods of achieving the hovering effect of architectonic structures (Structures / On-Paper)

D Structures / On-Paper

Example: Architectural Visualization Challenge II, HOVER, 2010 (Julio Cayetano)
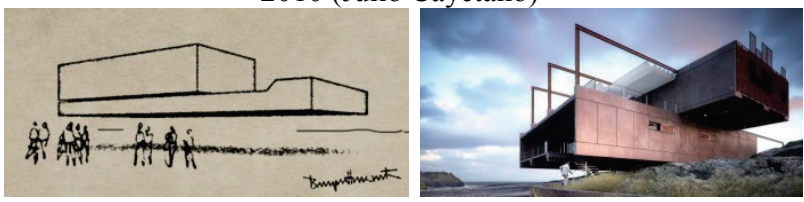

\section{Conclusion}

Through a historical analysis of the continuity of the considered concept and formal appearance of the mentioned structures in contemporary architecture, various ways of achieving the hovering effects of architectonic structures and the resulting classification are defined. The stress in the paper is on the geometrical setup and ratios of the structural elements. The $h / H$ factor was observed, which represents the relation between the horizon of an observer and the height to which the structure (or some of its parts) is elevated above the surface. During the classification, the context in which structures are located and the surface type have been taken into consideration. The environment of a structure, surface being its integral part, is an additional generator of the hovering effect, which may be seen in the proposed classification and given examples. The application of the hovering effect, or practical accomplishment of hovering of the architectonic structures, represents one of the trends in future architecture, which is deeply rooted in the entire architectonic history of the contemporary civilization.

\section{Acknowledgments}

The authors express their gratitude to the Ministry of Science and Technological Development of Serbia for providing partial support for this project (Grant No. 174012, Grant No. 33051 and Grant No. 36037).

\section{References}

[1] Viollet-le-Duc, E. E. Lectures on Architecture, Volume I. Dover Publications, Mineola, 1987.

[2] Nikolić, V.; Nikolić, O. Architecture Free from Support Architectonic Structures Illusion of Floating. // Proceedings of the International conference Mongeometrija, 2010, pp. 405-421.

[3] Browne, R. One Thousand and One Nights. Macmillan, 2013.

[4] Caracciolo, P. L. The Arabian Nights in English literature: studies in the reception of the Thousand and One Nights into British culture. Macmillan, 1988. DOI: 10.1007/978-1349-19620-3
[5] Jones, D. V. Castle in the Air, Greenwillow, New York, 1990.

[6] Karadžić, V. S. Narodne pripovijetke. Wien, 1870. pp. 7 10.

[7] Smith, W. A. Dictionary of Greek and Roman biography and mythology. Little, Brown and co., Boston, 1867.

[8] Hill, J. Actions of Architecture. Routledge, London, 2003.

[9] Tschumi, B. Architecture and Disjuctions: Collected Essays 1975-1990. MIT Press, London, 1996.

[10] Abel, C. Architecture, Technology and Process. Architectural Press, Elsevier, 2004.

[11] Xenakis, I.; Arnellos, A. The Relation between Interaction Aesthetics and Affordances. // Design Studies. 34, 1(2013), pp. 57-73. DOI: 10.1016/j.destud.2012.05.004

[12] Boner, L. Antonio Sant'Elia. te Neues, 2003.

[13] Giddings, B.; Horne, M. Artists' Impressions in Architectural Design. Spon Press, 2005.

[14] Dummett, E. Green Space and Cosmic Order: Le Corbusier's understanding of nature. // $\mathrm{PhD}$ thesis, University of Edinburgh, 2007.

[15] Kingsley, K. Charles Colbert. KnowLA Encyclopedia of Louisiana, Louisiana Endowment for the Humanities, 2010.

[16] Briegleb, T.; Raabe, C.; Schube, I. Roman Bezjak: Socialist Modernism. Hatje Cantz; Bilingual edition, 2011.

[17] Chaubin, F. Cosmic Communist Constructions Photographed. Taschen, 2011.

[18] Williams, R. J. Brasil - Modern Architectures in History. Reaktion Books, 2009.

[19] Petrović, M. Istorija moderne arhitekture - avangardni pokreti. Arhitektonski fakultet, Beograd, 2000.

[20] WAI. Lazar Khidekel and the Possibility of a Revolutionary Architecture. // Studio Magazine. Issue \#3 (2012).

[21] Gerst, C. Buckminster Fuller: Poet of Geometry. Overcup Press, Portland, 2013.

[22] White, J. Brave new sea worlds to redefine society. // New Scientist 09/2012; 215(2883), pp. 26-27.

[23] Sadler, S. Archigram: Architecture without Architecture, The MIT press, Cambridge, 2005.

[24] Walter, A. Winners of the Symbolic World Cup Structure Competition. 2013. http://archinect.com/news/article/ 78235170 (29.07.2013.)

[25] Tierney, T. Abstract Space beneath the Media Surface. Taylor \& Francis Group, 2007.

[26] Kostof, S. A. History of Architecture: Settings and Rituals. Oxford University Press, Oxford, 1995.

[27] Gombrich, E. Art and Illusion: A Study of Psychology of Pictorial Representation. Phaidon, London, 1960.

[28] Leyton, M. Shape as Memory: A Geometric Theory of Architecture. Birkhäuser - Publishers for Architecture, Switzerland, 2006

[29] Unwin, S. Analysing Architecture. Routledge, London, 2003. DOI: $10.4324 / 9780203413098$

[30] García, S. Distance to the Perspective Plane. // Nexus Network Journal. 5, 1(2005), pp. 22-48. DOl: 10.1007/s00004-002-0003-7

[31] Hunjet, A.; Parac, Đ. O.; Benšić. M. Yellow as a Dominant Tone. // Tehnicki vjesnik-Technical Gazette. 19, 1(2012), pp. 93-98.

[32] Todorović, D. Geometric and Perceptual Effects of the Location of the Observer Vantage Point for Linearperspective Images. // Perception. 34, 5(2005), pp. 521-544. DOI: $10.1068 /$ p5225 


\section{Authors' addresses}

Vladan Nikolić, PhD, assistant

University of Niš, Faculty of Civil Engineering and Architecture

Aleksandra Medvedeva st. 14

18000 Niš, Serbia

E-mail: vladan_nikolic@yahoo.com

\section{Ljiljana Radović, PhD, Associate Professor}

University of Niš, Faculty of Mechanical Engineering

Aleksandra Medvedeva st. 14

18000 Niš, Serbia

E-mail: ljradovic@gmail.com

\section{Olivera Nikolić, MSc}

University of Niš, Faculty of Civil Engineering and Architecture

Aleksandra Medvedeva st. 14

18000 Niš, Serbia

E-mail: o_milosavljevic@yahoo.com

Biserka Marković, PhD, full profesor

University of Niš, Faculty of Civil Engineering and Architecture Aleksandra Medvedeva st. 14

18000 Niš, Serbia

E-mail: ljradovic@gmail.com

Petar Mitković, PhD, full profesor

University of Niš, Faculty of Civil Engineering and Architecture Aleksandra Medvedeva st. 14

18000 Niš, Serbia

E-mail: dekan@gaf.ni.ac.rs

Mihailo Mitković, MSc, assistant

University of Niš, Faculty of Civil Engineering and Architecture

Aleksandra Medvedeva st. 14

18000 Niš, Serbia

E-mail: mihailo.mitkovic@yahoo.com

Jelena Đurić, MSc, assistant

University of Niš, Faculty of Civil Engineering and Architecture Aleksandra Medvedeva st. 14

18000 Niš, Serbia

E-mail: jelena_djuric@ymail.com 